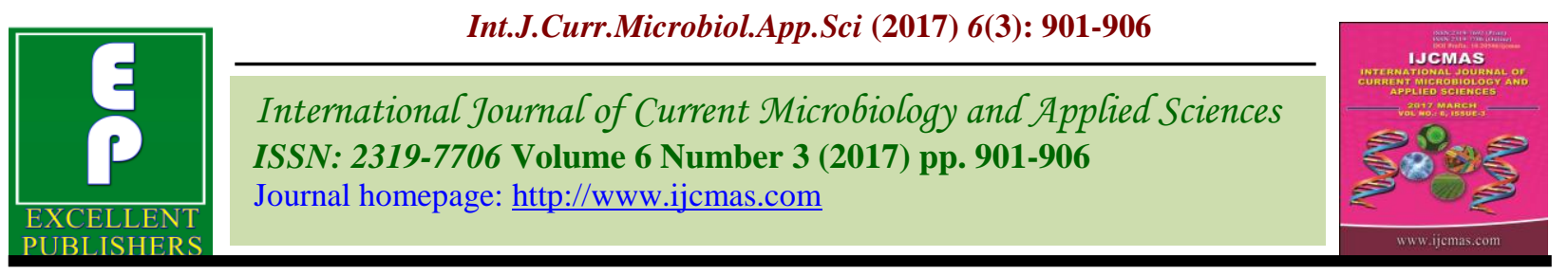

Original Research Article https://doi.org/10.20546/ijcmas.2017.603.106

\title{
Yield and Quality Parameters of Bt Cotton as Affected by Nitrogen Dose and its Scheduling
}

\author{
V.P. Verma, Ramanjit Kaur*, Y.S. Shivay, Anchal Dass and Seema Sepat \\ Division of Agronomy, ICAR-Indian Agricultural Research Institute, New Delhi-110 012, India \\ *Corresponding author:
}

\section{A B S T R A C T}

To study the effect of different rates and times of $\mathrm{N}$ application on productivity and fiber quality of Bt cotton, a field experiment was conducted during the rainy (June-November)

\begin{tabular}{|c|}
\hline Keywords \\
\hline $\begin{array}{l}\text { Bt Cotton, } \\
\text { Quality parameters, } \\
\text { yield, Lint yield. }\end{array}$ \\
\hline Article Info \\
\hline $\begin{array}{l}\text { Accepted: } \\
\text { 18 February } 2017 \\
\text { Available Online: } \\
10 \text { March } 2017\end{array}$ \\
\hline
\end{tabular}
seasons of 2014 at the research farm of ICAR-Indian Agricultural Research Institute, New Delhi, India. Nine treatments were formed by combinations of the two factors i.e. four $\mathrm{N}$ rates $\left(100,125,150\right.$, and $175 \mathrm{~kg} \mathrm{ha}^{-1}$ ) and two timings of $\mathrm{N}$ application (i.e. with $30 \mathrm{~kg} \mathrm{~N}$ $\mathrm{ha}^{-1}$ as basal and without basal) with a control. The experiment was conducted in a factorial randomised complete block design with four replications. Results revealed that seed cotton yield, cotton seed and lint yield was positively affected by $\mathrm{N}$ - application. The highest seed cotton yield $\left(2.65 \mathrm{t} \mathrm{ha}^{-1}\right)$, cotton seed $\left(1.73 \mathrm{t} \mathrm{ha}^{-1}\right)$ and lint yield $\left(0.93 \mathrm{t} \mathrm{ha}^{-1}\right)$ were recorded with $175 \mathrm{~kg} \mathrm{~N} \mathrm{ha}^{-1}$. The different quality parameters (ginning \%, micronaire (mg/inch), fiber elongation \%, 50\% span length, fiber strength (g/tex) and lint index) were also affected by $\mathrm{N}$ application. The highest values for ginning \% (34.9), fiber elongation \% (6.3), 50\% span length $(14.7 \mathrm{~mm})$ and lint index (5.1) recorded with $175 \mathrm{~kg} \mathrm{~N}^{-1}$ while for micronaire $(3.9 \mathrm{mg} / \mathrm{inch})$ was recorded with $150 \mathrm{~kg} \mathrm{~N}^{-1}$. The different quality parameters under study, recorded higher values with basal application of $\mathrm{N}$ compared with without basal application.

\section{Introduction}

Cotton is known as white gold and queen of fibers. It is an important cash crop of global significance which plays a dominant role in world agriculture and industrial economy. India is important grower of cotton on a global scale. In India, cotton is one of the major cash crops occupying an area of 12.5 million ha (mha) with the production of 35.48 million cotton bales (DAC, 2015-16). Production and productivity of cotton increased after the introduction of $B t$ cotton in the country. Research on cotton under various soil and climatic conditions has revealed beneficial effect of nitrogen $(\mathrm{N})$ application on the growth, yield and quality of cotton.
Nitrogen has a vital role in growth and development of cotton and beneficial effect of $\mathrm{N}$ on growth and development, yield (seed cotton and lint yield) and fiber quality have been proven by a number of research conducted in various environmental conditions. Nitrogen also prevents abscission of squares and bolls thus increase the number of bolls. Nitrogen also stimulates the mobilization and accumulation of photosynthates in newly form bolls, thus it increase the number of bolls and their weight. The crops like cotton, which have indeterminate growth behavior excess $\mathrm{N}$ causes delayed maturity, promote excessive 
vegetative growth, and usually results in lower seed cotton yields of inferior quality (Rinehardt et al., 2004). Unlike cereal crops, cotton is affected by both under and over application of $\mathrm{N}$. Nitrogen application less than optimum results in reduced boll formation and development, increased boll abscission, less seed cotton and lint yield, and reduce fiber quality like fiber length and strength. Over-fertilization results in excessive vegetative growth, decreased lint turnout, increased wilt disease incidence, delay in maturity which may results in to immature fiber, adversely affects lint yield and fiber quality (Main et al., 2011). An optimum supply of $\mathrm{N}$ is necessary for higher production of cotton crop. Beneficial effect of $\mathrm{N}$ was realize only with optimum $\mathrm{N}$ dose and it differed with growing conditions based on soil and prevailing environment conditions. In plants, deficiency symptoms (chlorosis) of $\mathrm{N}$ appear in older leaves being mobile in nature. The low $\mathrm{N}$ status of Indian soils especially dry land and also irrigated cotton tracts such as Punjab and Haryana (Devraj et al., 2008) indicates that its external application is must for realizing optimum productivity of this most important commercial crop of the country. The application rates vary from 20 $320 \mathrm{~kg} \mathrm{~N} \mathrm{ha}^{-1}$ in different parts of the country (Venugopalan and Blaise, 2009). The higher yield response and high $B t$ protein content with nitrogen application demands optimum $\mathrm{N}$ fertilization. The information on performance of $B t$ cotton under different nitrogen fertilization is lacking. Hence the present study was conducted to find the response of $B t$ cotton to different $\mathrm{N}$ rates and time of its application for higher productivity and economic returns.

\section{Materials and Methods}

The field experiment was carried out at Research Farm, Division of Agronomy, ICAR-Indian Agricultural Research Institute,
New Delhi, India, during the rainy seasons of 2013 and 2014. The experimental field is situated at $28^{\circ} 38^{\prime} \mathrm{N}$ latitude and $77^{\circ} 10^{\prime} \mathrm{E}$ longitude. The altitude is about $229 \mathrm{~m}$ above the mean sea level. The area comes under semi-arid and subtropical climate with very hot dry summers and cold winters. The experimental field had an even topography and a good drainage system. The soil of the experimental site was sandy loam, low in organic carbon $(0.43 \%)$ and available $\mathrm{N}$ $\left(177.7 \mathrm{~kg} \mathrm{ha}^{-1}\right)$, medium in phosphorus (11.6 $\mathrm{kg} \mathrm{ha}^{-1}$ ) and potassium (178.5 $\left.\mathrm{kg} \mathrm{ha}^{-1}\right)$, having $\mathrm{pH}$ of 7.6 and EC of $0.33 \mathrm{dSm}^{-1}$. There were two factors in the study, i.e. four $\mathrm{N}$ rates (100, 125,150 , and $175 \mathrm{~kg} \mathrm{ha}^{-1}$ ) and two timings of $\mathrm{N}$ application (i.e. with $30 \mathrm{~kg} \mathrm{~N} \mathrm{ha}^{-1}$ as basal and without basal). In the case of $30 \mathrm{~kg} \mathrm{~N}^{-1}$ as basal, this amount of $\mathrm{N}$ from the above rates was applied as basal dose and remaining quantities were applied in two splits. In case of no basal, the whole quantity of $\mathrm{N}$ was applied in two splits. A total of nine treatments were formed by combinations of above two factors with a control. The experiment was conducted in a factorial randomised complete block design with four replications. A medium duration $B t$ cotton variety MRC-7017 was used for the experiment. Recommended doses of phosphorus (60 kg $\mathrm{P}_{2} \mathrm{O}_{5} \mathrm{ha}^{-1}$ ) using single super phosphate and potassium $\left(60 \mathrm{~kg} \mathrm{~K}_{2} \mathrm{O}\right.$ $\mathrm{ha}^{-1}$ ) using potassium chloride (murate of potash) were applied as basal at the time of last preparatory tillage. Sowing was done manually by the dibbling method at row to row spacing of $75 \mathrm{~cm}$ and plant to plant spacing of $60 \mathrm{~cm}$. All other management practices were adopted as per standard procedure recommended for $B t$ cotton. Seed cotton yield from three pickings were weighed separately and were added to get seed cotton yield per net plot $\left(16.2 \mathrm{~m}^{2}\right)$. Based on area of net plot, seed cotton yield was expressed in $\mathrm{t} \mathrm{ha}^{-1}$. After ginning seed and lint were separated and weighed separately. The 
ginning percentage was computed using the given formula:

Ginning percentage $(\mathrm{GP})=$

Weight of lint

\section{Weight of seed cotton}

Lint index was computed using ginning percent and seed index data by using following formula

Lint index $=$

Seed index $\times$ Ginning percent (GP)

100- (GP)

Different quality parameters (length, strength and fineness of fiber) also analyzed. The fiber length was determined by 'Ball's sorter' where the weight ratio method was adopted and the mean length expressed in mm. Fiber strength is the ratio of the breaking strength of a bundle of fiber to its weight and is expressed in Tenacity ' 0 ' gauge. Fiber fineness is a measure of fiber weight in mg/unit length of the fiber. This was determined airflow method with the help of a micronaire.

\section{Results and Discussion}

\section{Seed cotton, seed and lint yield}

With each increase of $25 \mathrm{~kg} \mathrm{~N} \mathrm{ha}{ }^{-1}$, a significant increase in the seed cotton yield was observed up to $175 \mathrm{~kg} \mathrm{~N} \mathrm{ha}^{-1}$ (Table 1). The highest seed cotton yield was recorded with $175 \mathrm{~kg} \mathrm{~N} \mathrm{ha}^{-1}\left(2.65 \mathrm{t} \mathrm{ha}^{-1}\right)$ which was 25.6, 14.7, and $3.5 \%$ greater than that with 100,125 , and $150 \mathrm{~kg} \mathrm{~N} \mathrm{ha}^{-1}$, respectively. The seed cotton yield of $B t$ cotton was significantly affected by the time of nitrogen application. An increase of $5.1 \%$ in seed cotton yield was observed in the treatment where $30 \mathrm{~kg} \mathrm{~N}^{-1}$ was applied as the basal dose over the treatment where the basal $\mathrm{N}$ was not applied and significantly higher seed cotton yield (2.45 and $2.47 \mathrm{t} \mathrm{ha}^{-1}$ ) was obtained with the basal application of $\mathrm{N}$ compared to the treatment where the basal application of $\mathrm{N}$ was not applied $\left(2.35 \mathrm{t} \mathrm{ha}^{-1}\right)$. Among the different rates of $\mathrm{N}$ application, $175 \mathrm{~kg} \mathrm{~N} \mathrm{ha}^{-1}$ recorded significantly higher lint yield followed by 150 and $125 \mathrm{~kg} \mathrm{~N} \mathrm{ha}^{-1}$ (Table 1). The highest lint yield was recorded with $175 \mathrm{~kg} \mathrm{~N}^{-1}\left(0.93 \mathrm{t} \mathrm{ha}^{-1}\right)$ which was $30.9,17.7$, and $4.4 \%$ more than that obtained with 100, 125, and $150 \mathrm{~kg} \mathrm{~N} \mathrm{ha}{ }^{-1}$, respectively. The lint yield of $B t$ cotton was also significantly affected by the time of $\mathrm{N}$ application. The treatment having $30 \mathrm{~kg} \mathrm{~N}$ as the basal dose recorded significantly higher lint yield $\left(0.85 \mathrm{t} \mathrm{ha}^{-1}\right)$ than the treatment with no basal application $\left(0.81 \mathrm{t} \mathrm{ha}^{-1}\right)$. The maximum seed yield of $1.73 \mathrm{t} \mathrm{ha}^{-1}$ was recorded where the $\mathrm{N}$ was applied at $175 \mathrm{~kg}$ $\mathrm{ha}^{-1}$ followed by the $\mathrm{N}$ application rate of 150 $\mathrm{kg} \mathrm{ha}^{-1}\left(1.67 \mathrm{t} \mathrm{ha}^{-1}\right)$. The treatment with the basal application of $\mathrm{N}\left(30 \mathrm{~kg} \mathrm{ha}^{-1}\right)$ recorded significantly higher seed yield $\left(1.61 \mathrm{t} \mathrm{ha}^{-1}\right)$ as compared to the treatment where the basal application of $\mathrm{N}$ was not done (and $1.55 \mathrm{t} \mathrm{ha}^{-}$ ${ }^{1}$ ). Bhalerao et al., (2012) also reported that nitrogen enhanced cotton yields.

\section{Quality parameters}

\section{Ginning percentage}

The data pertaining to ginning percentage showed (Table 2) that different levels of $\mathrm{N}$ tested differ significantly for ginning percentage and each increase of $25 \mathrm{~kg} \mathrm{~N} \mathrm{ha}^{-1}$ significantly increase the ginning percentage up to $175 \mathrm{~kg} \mathrm{~N} \mathrm{ha}^{-1}$. Among the different levels of $\mathrm{N}$ application, the highest ginning percentage was recorded with $175 \mathrm{~kg} \mathrm{~N}^{-1}$ (34.9\%) which is $1.1 \%, 0.7 \%$ and $0.2 \%$ more than 100,125 and $150 \mathrm{~kg} \mathrm{~N}^{-1}$ respectively. The treatment having $30 \mathrm{~kg} \mathrm{~N}$ as basal dose 
recorded significantly higher ginning percentage over treatment with no basal application.

\section{$50 \%$ span length $(\mathrm{mm})$}

Data pertaining to $50 \%$ span length as influenced by nitrogen levels indicated that nitrogen had significant effect on the 50\% span length. Each increase of $25 \mathrm{~kg} \mathrm{~N} \mathrm{ha}^{-1}$ significantly increased the 50\% span length up to $175 \mathrm{~kg} \mathrm{~N} \mathrm{ha}^{-1}$. Among the different levels of $\mathrm{N}$ application the longest 50\% span length was observed with highest level of $\mathrm{N}$ i.e. $175 \mathrm{~kg} \mathrm{~N} \mathrm{ha}^{-1}$ which was $0.4 \mathrm{~mm}$ longer than $50 \%$ span length recorded with $100 \mathrm{~kg} \mathrm{~N}$ $\mathrm{ha}^{-1}(14.3 \mathrm{~mm})$. The effect of time of $\mathrm{N}$ application in respect of $50 \%$ span length was observed significant. The treatment having $30 \mathrm{~kg} \mathrm{~N}$ as basal dose recorded significantly longer $(14.6 \mathrm{~mm}) 50 \%$ span length than the treatment with no basal application. Result of present study was found similar to the results of Bradow and Davidonis, 2000.

\section{Uniformity ratio (\%)}

Data pertaining to uniformity ratio as influenced by nitrogen levels indicated that nitrogen had significant effect on the uniformity ratio (Table 2). Uniformity ratio is significantly decreased with increasing levels of $\mathrm{N}$ application. Amongst different levels, application of $125 \mathrm{~kg}$ of $\mathrm{N} \mathrm{ha}^{-1}$ recorded significantly higher $(48.4 \%)$ uniformity ratio compared to 100 and $150 \mathrm{~kg} \mathrm{~N} \mathrm{ha}^{-1}$. The lowest uniformity ratio was recorded with 175 $\mathrm{kg} \mathrm{N} \mathrm{ha}{ }^{-1}$. Significant effect of time of $\mathrm{N}$ application in respect of uniformity ratio was observed. The treatment having $30 \mathrm{~kg} \mathrm{~N}$ as basal dose recorded significantly higher uniformity ratio than the treatment with no basal application. Reddy et al., (2004) also reported that the uniformity ratio decreased with increasing levels of $\mathrm{N}$.

Table.1 Effect of variable rate of $\mathrm{N}$-application on yield $\left(\right.$ tha $\left.^{-1}\right)$ and Ginning (\%) of Bt cotton

\begin{tabular}{lllll}
\hline Treatments & Seed cotton yield & Lint yield & Seed yield & Ginning \% \\
\hline Nitrogen levels (kgha-1) & & & & \\
100 & 2.11 & 0.71 & 1.40 & 33.8 \\
125 & 2.31 & 0.79 & 1.52 & 34.2 \\
150 & 2.56 & 0.89 & 1.67 & 34.7 \\
175 & 2.65 & 0.93 & 1.73 & 34.9 \\
SEm \pm & 0.014 & 0.005 & 0.009 & 0.03 \\
LSD $(P=0.05)$ & 0.040 & 0.015 & 0.025 & 0.10 \\
Time of application & & & & \\
No basal only 2 splits & 2.35 & 0.81 & 1.55 & 34.2 \\
Basal + 2 splits & 2.47 & 0.85 & 1.61 & 34.5 \\
SEm \pm & 0.010 & 0.004 & 0.006 & 0.02 \\
LSD $(P=0.05)$ & 0.028 & 0.011 & 0.018 & 0.07 \\
Control vs Rest & & & & \\
Control & 1.39 & 0.45 & 0.94 & 32.2 \\
Rest & 2.41 & 0.83 & 1.58 & 34.4 \\
SEm \pm & 0.021 & 0.008 & 0.013 & 0.050 \\
LSD $(P=0.05)$ & 0.043 & 0.016 & 0.027 & 0.104 \\
\hline
\end{tabular}


Table.2 Effect of variable rate of $\mathrm{N}$-application on quality of Bt cotton

\begin{tabular}{|c|c|c|c|c|c|c|}
\hline Treatments & $\begin{array}{l}\text { Micronaire } \\
\mathrm{mg} / \text { inch) }\end{array}$ & $\begin{array}{l}50 \% \text { span } \\
\text { length }(\mathrm{mm})\end{array}$ & $\begin{array}{l}\text { Uniformity } \\
\text { ratio }(\%)\end{array}$ & $\begin{array}{l}\text { Fiber strength } \\
(\mathrm{g} / \text { tex })\end{array}$ & $\begin{array}{l}\text { Fiber elongation } \\
(\%)\end{array}$ & $\begin{array}{l}\text { Lint } \\
\text { index }\end{array}$ \\
\hline \multicolumn{7}{|l|}{ Nitrogen levels (kgha-1) } \\
\hline 100 & 3.8 & 14.3 & 47.7 & 22.7 & 6.2 & 4.2 \\
\hline 125 & 3.9 & 14.6 & 48.4 & 22.7 & 6.2 & 4.4 \\
\hline 150 & 3.9 & 14.6 & 47.6 & 22.0 & 6.3 & 4.8 \\
\hline 175 & 3.8 & 14.7 & 45.9 & 21.4 & 6.3 & 5.1 \\
\hline SEm \pm & 0.03 & 0.02 & 0.10 & 0.03 & 0.02 & 0.02 \\
\hline $\operatorname{LSD}(P=0.05)$ & 0.08 & 0.06 & 0.29 & 0.09 & 0.05 & 0.05 \\
\hline \multicolumn{7}{|l|}{ Time of application } \\
\hline No basal only 2 splits & 3.9 & 14.5 & 47.1 & 22.1 & 6.3 & 4.5 \\
\hline Basal + 2 splits & 3.9 & 14.6 & 47.7 & 22.3 & 6.3 & 4.7 \\
\hline $\mathrm{SEm} \pm$ & 0.02 & 0.02 & 0.07 & 0.02 & 0.01 & 0.01 \\
\hline $\operatorname{LSD}(P=0.05)$ & NS & 0.04 & 0.21 & 0.07 & NS & 0.03 \\
\hline \multicolumn{7}{|l|}{ Control vs Rest } \\
\hline Control & 3.7 & 14.0 & 45.2 & 21.9 & 5.9 & 3.2 \\
\hline Rest & 3.9 & 14.5 & 47.4 & 22.2 & 6.3 & 4.6 \\
\hline $\mathrm{SEm} \pm$ & 0.04 & 0.03 & 0.15 & 0.05 & 0.03 & 0.02 \\
\hline $\operatorname{LSD}(P=0.05)$ & 0.08 & 0.07 & 0.31 & 0.10 & 0.06 & 0.05 \\
\hline
\end{tabular}

\section{Fiber strength}

The data on fiber strength as influenced by $\mathrm{N}$ levels and time of $\mathrm{N}$ application was recorded and presented in table 2, revealed that nitrogen had significant effect on the fiber strength. The fiber strength was highest at lower level of $\mathrm{N}$ application and decrease with increase in $\mathrm{N}$ levels up to $175 \mathrm{~kg} \mathrm{~N} \mathrm{ha}^{-1}$. Amongst different levels of $\mathrm{N}$, application of $100 \mathrm{~kg}$ of $\mathrm{N} \mathrm{ha}^{-1}$ recorded significantly higher fiber strength which was statistically at par with $125 \mathrm{~kg} \mathrm{~N} \mathrm{ha}^{-1}$.

The lowest fiber strength was observed with application of $175 \mathrm{~kg} \mathrm{~N} \mathrm{ha}{ }^{-1}$. The fiber strength was significantly affected by time of $\mathrm{N}$ application. The treatment with basal application of $\mathrm{N}\left(30 \mathrm{~kg} \mathrm{ha}{ }^{-1}\right)$ recorded significantly higher fiber strength as compare to the treatment where basal application of $\mathrm{N}$ was not done.

Bradow and Davidonis, 2000 also reported that the application of higher rates of $\mathrm{N}$ decrease the fiber strength.

\section{Fiber elongation $(\%)$}

The data on fiber elongation as influenced by $\mathrm{N}$ levels and time of $\mathrm{N}$ application was recorded and presented in table 2, postulated that different levels of $\mathrm{N}$ tested differ significantly for fiber elongation. Among the different levels of $\mathrm{N}$ application of $175 \mathrm{~kg} \mathrm{~N}$ $\mathrm{ha}^{-1}$ recorded higher fiber elongation which is at par with $150 \mathrm{~kg} \mathrm{~N} \mathrm{ha}^{-1}$. Time of nitrogen application recorded non-significant differences in treatments.

\section{Micronaire (mg/inch)}

The data on micronaire value as influenced by $\mathrm{N}$ levels and time of $\mathrm{N}$ application was recorded and presented in table 2 , indicated that nitrogen had significant effect on the fiber strength. Among the different levels of $\mathrm{N}$ application of $100 \mathrm{~kg}$ of $\mathrm{N} \mathrm{ha}^{-1}$ recorded significantly lower micronaire value which was same and at par with $175 \mathrm{~kg} \mathrm{~N} \mathrm{ha}^{-1}$. The effect of time of application of nitrogen on micronaire was found non-significant. Reddy et al., (2004) also reported similar finding in 
respect of $\mathrm{N}$ levels and micronaire values of $B t$ cotton.

\section{Lint index}

The lint index was significantly influenced by $\mathrm{N}$ fertilization. Increase in $\mathrm{N}$ dose increased lint index and the significant difference was recorded up to $175 \mathrm{~kg} \mathrm{~N}^{-1}$. Application of $175 \mathrm{~kg} \mathrm{~N} \mathrm{ha}^{-1}$ recorded the highest lint index value (5.1) and the lowest lint index value (4.2) was observed in the treatment receiving $100 \mathrm{~kg}$ $\mathrm{N} \mathrm{ha}^{-1}$. Time of $\mathrm{N}$ application also significantly affected the lint index. The treatment having 30 $\mathrm{kg} \mathrm{N}$ as basal dose recorded significantly higher lint index over treatment with no basal application. The results of present investigation in respect to ginning percentage and lint index in relation to nitrogen fertilization are in tune with the findings of Sawan et al., (2006).

A significant increase in the seed cotton yield and lint yield up to $175 \mathrm{~kg} \mathrm{~N} \mathrm{ha}^{-1}$ was obtained with each increase of $25 \mathrm{~kg} \mathrm{~N}^{-1}$. Amongst different levels of $\mathrm{N}$ application, $175 \mathrm{~kg}$ of $\mathrm{N}$ $\mathrm{ha}^{-1}$ recorded significantly higher seed cotton yield than rest of the treatments. Ginning \%, seed index, lint index, 50\% span length and fiber elongation tended to increase with increase in $\mathrm{N}$ fertilization up to $175 \mathrm{~kg} \mathrm{ha}^{-1}$ whereas, fiber strength, uniformity ratio value tended to decrease with increasing $\mathrm{N}$ fertilization.

\section{References}

Bhalerao, P.D., Deshmukh, P.W., Gaikwad, G.S. and Imade, S.R. 2012. Response of Bt. cotton (Gossypium hirsutum) to spacing and fertilizer levels under rainfed conditions. Indian J. Agron., 57(2): 17679 .
Department of Agriculture and Cooperation, annual report 2014-15 Ministry of Agriculture Government of India, Krishi Bhawan, New Delhi 110001 India.

Devraj, Sharma, A.P., Singh, U.V. and Duhan, B.S. 2008. Studies on fertility status of cotton growing soils of Haryana, $J$. Cotton Res. Develop., 22(1): 81-84.

Main, C.L., Barber, L.T., Dodds, D.M., Duncan, S.R., Edmisten, K.L., Jones, M.A., Whitaker, J.R., Morgan, G., Osborne, S., Boman, R.K., Norton, R. and Nichols, R.L. 2011. Cotton cultivar response to nitrogen fertilization. Proceeding belt wide cotton conference, Atlanta, GA. 4-7 January. National Cotton Council, Memphis, TN.

Reddy, K.R., Koti, S., Davidonis, G.H., Reddy, V.R., 2004. Interactive effects of carbon dioxide and nitrogen nutrition on cotton growth, development, yield and fiber quality, Agron. J., 96: 1148-1157.

Rinehardt, J.M., Edmisten, K.L., Wells, R. and Faircloth, J.C. 2004. Response of ultranarrow and conventional spaced cotton to variable nitrogen rates, J. Plant Nutrition, 27: 743-755.

Sawan, Z.M., Mahmoud, M.H. and El-Guibali, A.H. 2006. Response of yield, yield components, and fiber properties of Egyptian cotton (Gossypium barbadense L.) to nitrogen fertilization and foliarapplied potassium and mepiquat chloride, J. Cotton Sci., 10: 224-234.

Venugopalan, M.V. and Blaise, D. 2009. NPK fertilization on cotton. In: Brainstorming session on crop response and nutrient ratio organised at National Academy of Agricultural Sciences, 28-29 May 2009. pp. 15-119.

\section{How to cite this article:}

Verma, V.P., Ramanjit Kaur, Y.S. Shivay, Anchal Dass, Seema Sepat. 2017. Yield and Quality Parameters of $\mathrm{Bt}$ Cotton as Affected by Nitrogen Dose and its Scheduling. Int.J.Curr.Microbiol.App.Sci. 6(3): 901-906. doi: https://doi.org/10.20546/ijcmas.2017.603.106 